\title{
Radiopacity evaluation of Portland and MTA-based cements by digital radiographic system
}

\author{
Alvaro Henrique BORGES ${ }^{1}$, Fabio Luiz Miranda PEDRO'1, Alex SEMANOFF-SEGUNDO', \\ Carlos Eduardo Saraiva MIRANDA², Jesus Djalma PÉCORA ${ }^{3}$, Antônio Miranda CRUZ FILHO ${ }^{3}$ \\ 1- DDS, MSc, PhD, Department of Endodontics, Dental School, University of Cuiabá, Cuiabá, MT, Brazil.
2- DDS, MSc, PhD, Department of Restorative Dentistry, Ribeirão Preto Dental School, University of São Paulo, Ribeirão Preto, SP, Brazil.
3- DDS, MSc, PhD, Department of Chemistry, University of Ribeirão Preto, Ribeirão Preto, SP, Brazil.
}

Corresponding address: Antônio Miranda da Cruz Filho - Praça Pompilio Conceição, casa 10 - Residencial Vila Aliança, Jd. Botânico - $14021-594$ - Ribeirão Preto, SP - Brasil - Phone: +55-16-3234-9551 - Fax: +55-16-3602-4792 - e-mail: cruz@forp.usp.br

Received: July 29, 2009 - Modification: February 16, 2010 - Accepted: May 25, 2010

\section{ABSTRACT}

\begin{abstract}
$\mathrm{O}$ bjective: The aim of the present study was to evaluate the radiopacity of Portland and MTA-based cements using the Digora TM digital radiographic system. Material and Methods: The performed tests followed specification number 57 from the American National Standard Institute/American Dental Association (2000) for endodontic sealing materials. The materials were placed in 5 acrylic plates, especially designed for this experiment, along with a graduated aluminum stepwedge varying from 1 to $10 \mathrm{~mm}$ in thickness. The set was radiographed at a $30 \mathrm{~cm}$ focus-object distance and with $0.2 \mathrm{~s}$ exposure time. After the radiographs were taken, the optical laser readings of radiographs were performed by Digora TM system. Five radiographic density readings were performed for each studied material

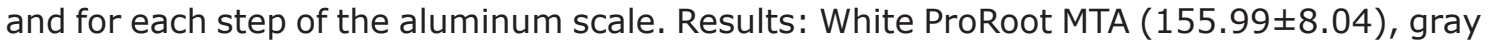
ProRoot MTA (155.96 \pm 16.30$)$ and MTA BIO (143.13 \pm 16.94$)$ presented higher radiopacity values $(p<0.05)$, while white non-structural Portland $(119.76 \pm 22.34)$, gray Portland $(109.71 \pm 4.90)$ and white structural Portland $(99.59 \pm 12.88)$ presented lower radiopacity values $(p<0.05)$. Conclusions: It was concluded that MTA-based cements were the only materials presenting radiopacity within the ANSI/ADA specifications.
\end{abstract}

Key words: Endodontics. Dental radiography. Digital radiography. Radiology. Retrograde obturation. Root canal filling materials.

\section{INTRODUCTION}

The role of endodontic sealers is to establish a perfect and hermetic periapical environment seal ${ }^{18}$. Ideally, these materials should be biocompatible with periradicular tissues, non-absorbable, adaptable to dentin walls and should present good handling characteristics and no cytotoxicity 6,19,22,23.

Mineral trioxide aggregate (MTA)-based cements have been widely investigated for endodontic applications ${ }^{19}$. The use of MTA as retrofilling material, in animals, has shown an induction of lower inflammatory response ${ }^{4}$. MTA has been also employed for pulp capping ${ }^{20}$, in root perforations reparation ${ }^{18}$ and as barrier for teeth with open apexes $^{13}$.

Although MTA is known for its superiority compared to other retrofilling materials, it is more expensive, limiting its use. Biocompatibility studies comparing MTA and Portland cements have shown similar results ${ }^{22}$. Most components are similar for both materials ${ }^{10}$. Bismuth oxide, which is responsible for radiopacity, is present in MTA, but not in Portland cement ${ }^{10,12}$. This material is classified as structural or non-structural cement. Structural cement presents high quantities of carbonatic material in its composition, being responsible for material resistance ${ }^{2}$.

The ideal filling material should present sufficient radiopacity to be distinguished from dental structures and be evaluated inside the cavity ${ }^{24}$. Studies evaluating radiopacity employ an aluminum stepwedge, and more recently, digital methods that determine gray values have been proposed ${ }^{3}$, involving radiograph digitization and the use of specific software to determine the 
pixel gray values ${ }^{25}$. In this process, these values are converted into millimeters of aluminium equivalent and related to radiopacity of materials ${ }^{5}$. Using a digital radiography system, this study evaluated the radiopacity of Portland and MTAbased cements according to the American National Standard Institute/American Dental Association's specification \#57 for endodontic sealing materials ${ }^{1}$.

\section{MATERIAL AND METHODS}

Five acrylic plates $(2.2 \mathrm{~cm} \times 4.5 \mathrm{~cm} \times 1 \mathrm{~mm})$ with 6 holes measuring $1 \mathrm{~mm}$ in depth and $5 \mathrm{~mm}$ of internal diameter were fabricated ${ }^{5}$. The acrylic plates were placed onto a glass plate covered by cellophane paper and each orifice was filled with one of the tested cements (Figure 1 ).

For the radiographic exposure, each acrylic plate containing the cements was positioned together with another acrylic plate $(1.3 \mathrm{~cm} \times 4.5 \mathrm{~cm} \times 1 \mathrm{~mm})$, which contained a graduated aluminum stepwedge varying from 1 to $10 \mathrm{~mm}$ in thickness, and uniform steps of $1 \mathrm{~mm}$ each ${ }^{1}$.

The set of plates was built with standardized measurements in a way that they would correspond exactly to the sensor size (phosphor plate), from Digora TM system (Soredex, Orion Corporation, Helsink, Finland), used for data collection. A 70 $\mathrm{kVp}$ and $8 \mathrm{~mA}$ radiograph machine, Spectro 70X (Dabi Atlante, Dabi Atlante Indústrias Médico Odontológicas Ltda, Ribeirão Preto, SP, Brazil), was used. The focus-object distance was $30 \mathrm{~cm}$ (ANSI/ ADA 2000) and exposure time at $0.2 \mathrm{~s}$, as instructed for digital radiography of phosphor plates, by the manufacturer (Figure 2).

An acrylic positioning device with metallic fastener held sensors and provided an adequate and standardized focus-object distance. The radiograph machine head was fixed on the same position with central beam presenting $90^{\circ}$ angle of incidence with the acrylic/sensor surface plates set. A rectangular collimator (Dabi Atlante, Dabi Atlante Indústrias Médico Odontológicas Ltda) presenting $3 \times 4 \mathrm{~cm}$ aperture reduced possible secondary radiation by being attached to the end of cylinder.

The sensor, after being exposed, was inserted into the laser optical reader of Digora ${ }^{\mathrm{TM}}$ for Windows 5.1 software. As soon as the first image was revealed on screen, parameters suggested by the system were established, allowing to image standardization. The same phosphor plate was used for all exposures to avoid possible differences between plates.

The system performed a radiographic density reading over images of each cement revealed on screen, and also a reading of steps on an aluminum stepwedge, resulting in a numeric value for each reading. This value was written down by the evaluator. After evaluating the 5 acrylic set of plates, 5 measurements for each type of cement and for each step of the aluminum scale were obtained. Mean values of radiographic density and graduated aluminum stepwedge were determined for each material. Mean values were taken by a single evaluator previously trained and blinded with regard to the different groups. Intergroup relation analysis was tested using one-way ANOVA $(\alpha=0.05)$. Pairwise multiple comparisons were carried out using the Bonferroni test $(\alpha=0.05)$ in the cases where the ANOVA test showed significant differences.

\section{RESULTS}

The mean radiographic density values of the cements, in $\mathrm{mm} \mathrm{Al}$, are presented in Table 1. MTAbased cements (MTA BIO, gray and white ProRoot MTA) presented the highest radiopacity values

\begin{tabular}{|c|c|c|}
\hline Root canal sealer & Composition* & Manufacturer \\
\hline White structural Portland & $\begin{array}{l}\text { White clinker (100-75\%), Gypsum (3\%) and Carbonate } \\
\text { Material }(0-25 \%)\end{array}$ & $\begin{array}{l}\text { Votorantim Cimentos Brasil } \\
\text { S/A, Votorantim, SP, Brazil }\end{array}$ \\
\hline Gray Portland & Gray clinker (97\%) and Gypsum (3\%) & $\begin{array}{l}\text { Votorantim Cimentos Brasil } \\
\text { S/A, Votorantim, SP, Brazil }\end{array}$ \\
\hline White non-structural Portland & $\begin{array}{l}\text { White clinker (74-50\%), Gypsum (3\%) and Carbonate } \\
\text { Material }(26-50 \%)\end{array}$ & $\begin{array}{l}\text { Votorantim Cimentos Brasil } \\
\text { S/A, Votorantim, SP, Brazil }\end{array}$ \\
\hline MTA BIO & Portland Cement ( $80 \%)$ and Bismuth oxide (20\%) & $\begin{array}{c}\text { Angelus Ind. Prod., Londrina, } \\
\text { PR, Brazil }\end{array}$ \\
\hline Gray ProRoot MTA & $\begin{array}{l}\text { Portland Cement (75\%), Bismuth oxide (20\%) and } \\
\text { Gypsum (5\%) }\end{array}$ & $\begin{array}{l}\text { Dentsply-Tulsa Dental, } \\
\text { Tulsa, OK, USA }\end{array}$ \\
\hline White ProRoot MTA & $\begin{array}{l}\text { Portland Cement (75\%), Bismuth oxide (20\%) and } \\
\text { Gypsum (5\%) }\end{array}$ & $\begin{array}{l}\text { Dentsply-Tulsa Dental, } \\
\text { Tulsa, OK, USA }\end{array}$ \\
\hline
\end{tabular}

*information according to the manufacturers

Figure 1- Tested materials and compositions 


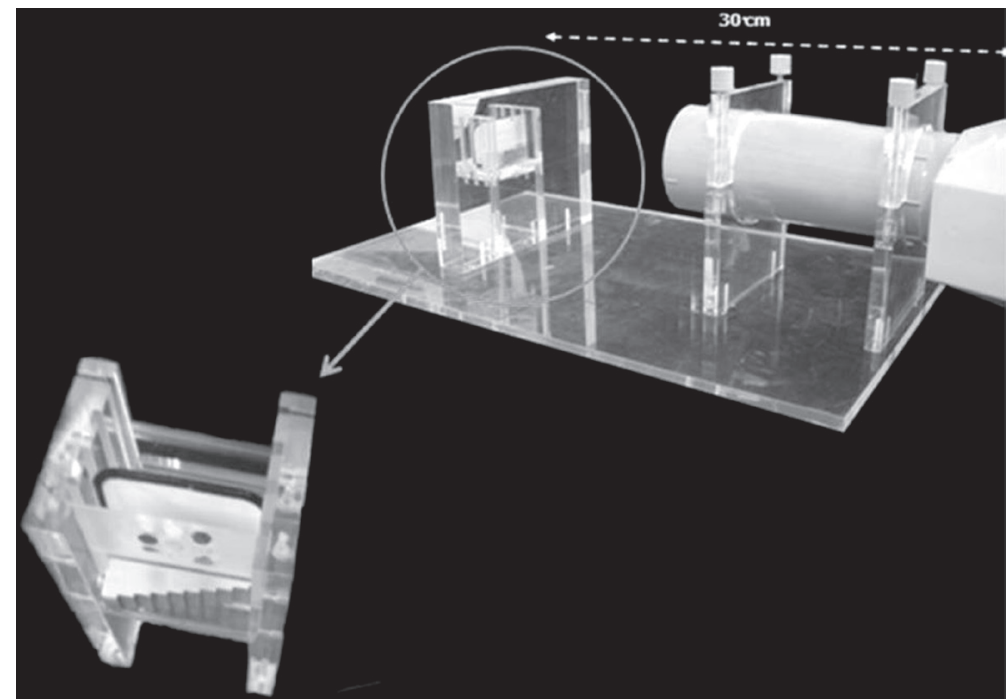

Figure 2- Experimental set-up used to fix x-ray machine central beam and the acrylic plates/phosphor plate set at a focusobject distance of $30 \mathrm{~cm}$. In greater magnification, experimental set-up with the aluminium stepwedge, wells for root canal filling materials and radiography digital phosphor plate

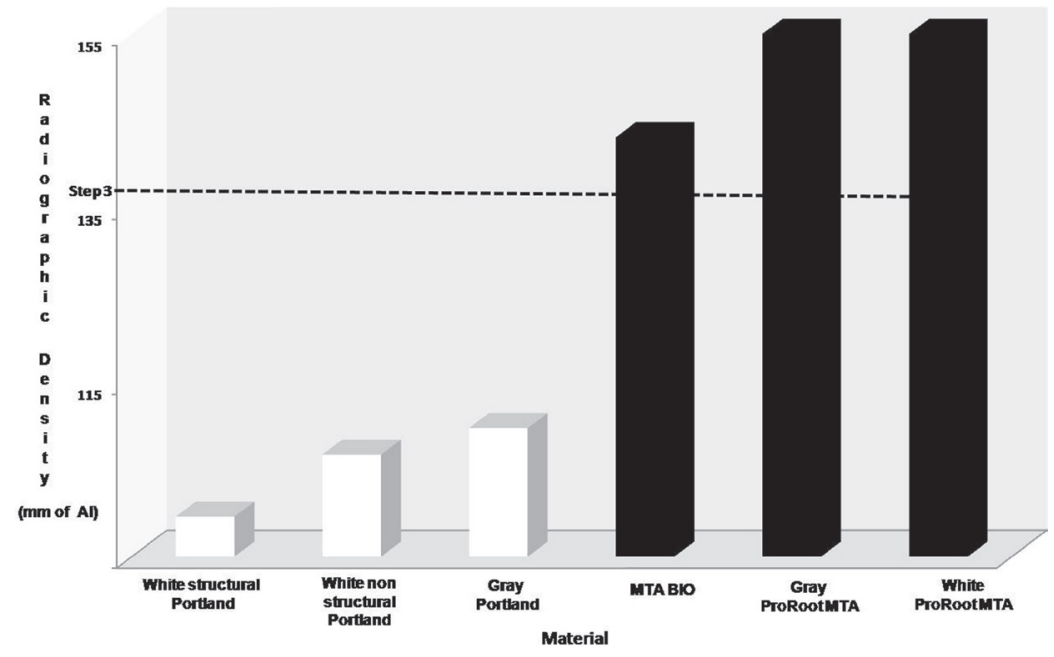

Figure 3- Radiopacity of cements in comparison with steps of the aluminium scale. The black color relates to cements whose radiopacity density ( $\mathrm{mm} \mathrm{Al}$ ) fulfills the ANSI-ADA specification number 57 (step 3 ). The white color refers to cements with radiopacity lower than the value recommended by the ANSI-ADA

Table 1- Radiographic density of the cements (mean \pm standard deviation)

\begin{tabular}{lc}
\hline Root canal sealer & $\begin{array}{c}\text { Radiographic } \\
\text { density (mm Al) }\end{array}$ \\
\hline White structural Portland & $99.59 \pm 12.88^{\mathrm{a}}$ \\
\hline Gray Portland & $109.71 \pm 4.90^{\mathrm{a}}$ \\
\hline White non-structural Portland & $119.76 \pm 22.34^{\mathrm{a}}$ \\
\hline MTA BIO & $143.13 \pm 16.94^{\mathrm{b}}$ \\
\hline Gray ProRoot MTA & $155.96 \pm 16.30^{\mathrm{b}}$ \\
\hline White ProRoot MTA & $155.99 \pm 8.04^{\mathrm{b}}$ \\
\hline
\end{tabular}

Radiopacity means \pm standard deviation of the tested materials and results of ANOVA and Bonferroni test $(\alpha=0.05)$. Different letters indicate statistically significant differences at $5 \%$ significance level. among the tested materials $(p<0.05)$, overcoming 3 steps from the aluminum stepwedge, which is the minimum radiopacity recommended by the ANSI/ ADA specification number $57^{1}$ (Figure 3 ).

No statistically differences were observed between each other. Portland cements (gray, white structural and white non-structural) presented the lowest radiopacity values $(p<0.05)$, not reaching the ANSI/ADA $^{1}$ (2000) recommendation.

\section{DISCUSSION}

Up to present moment, there are no specific standards for retrofilling materials to support and reference studies on their physico-chemical properties. Published studies followed standards proposed by the ANSI/ADA specification number 
$57^{1}$ for endodontic sealing materials ${ }^{11,27}$, and the ISO 6876 standard for zinc oxide and eugenol endodontic sealing materials ${ }^{6,15}$. This equivalence is based on the fact that, under clinical conditions, retrofilling materials and root filling materials remain in direct contact with periodontal and periapical tissues ${ }^{8,18}$.

Both ISO and ANSI/ADA have adopted equivalence procedures with an aluminium scale steps, in order to analyze several dental materials radiopacity ${ }^{3}$. It is known that the radiopacity of 1 $\mathrm{mm}$ of dentin is equivalent to $1 \mathrm{~mm}$ of aluminum in a graduated stepwedge ${ }^{9}$. According to the ANSI/ ADA specification number $57^{1}$, an endodontic sealing material should present radiopacity correspondent to at least $3 \mathrm{~mm} \mathrm{Al}$.

Digital measurement methods have been proposed by determining gray-tones values, measured in pixels ${ }^{21}$. These systems can differentiate all shades of gray on a digital image, while the naked human eye cannot identify 255 shades, on a non-digitized film ${ }^{5}$. Some studies used direct methods of analysis ${ }^{5}$, while others preferred indirect methods, through scanning images obtained by occlusal films ${ }^{25,26}$. Besides, digital $x$-ray films provide reduction in processing time and in number of steps that could interfere on final radiograph quality ${ }^{21}$.

Retrofilling materials should present enough radiopacity to be radiographically distinguished from surrounding structures, such as tooth and alveolar bone, and to reveal empty spaces and inappropriate contours $^{17}$. Only gray and white ProRoot MTA cements and MTA BIO, among the studied materials, met the ANSI/ADA recommendations. This fact was expected since ProRoot MTA and MTA BIO are reinforced with $20 \%$ bismuth oxide in their composition 7,10 . However, other studies reported a lower quantity of bismuth oxide on MTA BIO composition, justifying its lower radiopacity in comparison to ProRoot MTA, corroborating with this study's findings ${ }^{6,8,16}$.

The original formulation of Portland cement did not present bismuth oxide ${ }^{10}$, determining its low radiopacity and making impossible to distinguish it from bone tissue ${ }^{14}$. Mean values obtained for this cement were lower than $2 \mathrm{~mm} \mathrm{Al}$, not reaching the minimum requirements of the ANSI/ADA ${ }^{1}$ (2000). The inadequate radiopacity of Portland cement has been reported ${ }^{8}$. In order to address this issue, radiopacity was studied when Portland cement was associated to different radiopacifiers ${ }^{14}$. Results demonstrated that incorporation of a radiopacifier agent promotes satisfactory radiopacity, being also higher than dentin radiopacity ${ }^{14}$. However, it should be further investigated if the cement/radiopacifier agent mixture does not interfere with the original physicochemical properties and biocompatibility of Portland cements.

\section{CONCLUSIONS}

Based on the employed methodology and obtained results, it can be concluded that only MTA-based cements met the ANSI/ADA specification number $57^{1}$ with respect to radiopacity.

\section{REFERENCES}

1- American Dental Association - ANSI/ADA. Specification 57: endodontic sealing material. Chicago: ANSI/ADA; 2000.

2- Associação Brasileira de Cimento Portland. Guia básico de utilização do cimento Portland. 7ª. ed. São Paulo; 2002.

3- Baksi GB, Sen BH, Eyuboglu TF. Differences in aluminium equivalent values of endodontic sealer: conventional versus digital radiography. J Endod. 2008;34:1101-4.

4- Bernabé PFE, Holland R, Morandi R, Souza V, Nery MJ, Otoboni Filho JA, et al. Comparative study of MTA and other materials in retrofilling of pulpless dogs' teeth. Braz Dent J. 2005; 16:149-55. 5- Carvalho JR Jr, Correr-Sobrinho L, Correr AB, Sinhoreti MA, Consani S, Sousa-Neto MD. Radiopacity of root filling materials using digital radiography. Int Endod J. 2007;40:514-20.

6- Chng HK, Islam I, Yap AUJ, Tong YW, Koh ET. Properties of a new root-end filling material. J Endod. 2005;31:665-8.

7- Dammaschke T, Gerth HUV, Züchner H, Schäfer E. Chemical and physical surface and bulk material characterization of white ProRoot MTA and two Portland cements. Dent Mat. 2005;21:731-8. 8- Danesh G, Dammaschke T, Gerth HUV, Zandbiglari T, Schäfer E. A comparative study of selected properties of ProRoot mineral trioxide aggregate and two Portland cements. Int Endod J. 2006;39:213-9.

9- Devito KL, Ortega AI, Haiter-Neto F. Radiopacity of calcium hydroxide cement compared with human tooth structure. J Appl Oral Sci. 2004;12:290-3.

10- Estrela C, Bammann LL, Estrela CRA, Silva RS, Pécora JD. Antimicrobial and chemical study of MTA, Portland cement, calcium hydroxide paste, Sealapex and Dycal. Braz Dent J. 2000;11:3-9. 11- Fridland M, Rosado R. Mineral trioxide aggregate (MTA) solubility and porosity with different water-to-powder ratios. J Endod. 2003;29:814-7.

12- Funteas UR, Wallace JA, Fochtman EW. A comparative analysis of mineral trioxide aggregate and Portland cement. Aust Endod J. $2003 ; 29: 43-4$.

13- Hayashi M, Shimizu A, Ebisu S. MTA for obturation of mandibular central incisors with open apices: case report. J Endod. 2004;30:120-2.

14- Húngaro Duarte MA, Oliveira El Kadre GD, Vivan RR, Guerreiro Tanomaru JM, Tanomaru Filho M, Moraes IG. Radiopacity of portland cement associated with different radiopacifying agents. J Endod. 2009;35:737-40.

15- International Organization for Standardization. ISO 6876: dental root canal sealing materials. $2^{\text {nd }}$ ed. Geneva: ISO; 2001. 16- Islam I, Chng HK, Yap AU. Comparison of the physical and mechanical properties of MTA and Portland cement. J Endod. 2006;32:193-7.

17- Laghios CD, Benson BW, Gutmann JL, Cutler CW. Comparative radiopacity of tetracalcium phosphate and other root-end filling materials. Int Endod J. 2000;33:311-5.

18- Martins GR, Carvalho CAT, Valera MC, Oliveira LD, Buso L, Carvalho AS. Sealing ability of castor oil polymer as a root-end filling material. J Appl Oral Sci. 2009;17:220-3.

19- Oliveira MG, Xavier CB, Demarco FF, Pinheiro ALB, Costa AT, Pozza DH. Comparative chemical study of MTA and Portland cements. Braz Dent J. 2007;18:3-7.

20- Queiroz AM, Assed S, Leonardo MR, Nelson-Filho P, Silva LAB. MTA and calcium hydroxide for pulp capping. J Appl Oral Sci. $2005 ; 13: 126-30$. 
21- Rasimick BJ, Shah RP, Musikant BL, Deutsch AS. Radiopacity of endodontic materials on film and a digital sensor. J Endod. 2007;33:1098-101.

22- Ribeiro DA, Matsumoto MA, Duarte MAH, Marques MEA, Salvadori DMF. In vitro biocompatibility tests of two commercial types of mineral trioxide aggregate. Braz Oral Res. 2005;19:183-7. 23- Saidon J, He J, Zhu Q, Safavi K, Spångberg LSW. Cell and tissue reactions to mineral trioxide aggregate and Portland cement. Oral Surg Oral Med Oral Pathol Oral Radiol Endod. 2003;95:483-9. 24- Tagger M, Katz A. A standard for radiopacity of root-end (retrograde) filling materials is urgently needed. Int Endod J. 2004;37:260-4.

25- Tanomaru-Filho M, Jorge EG, Guerreiro Tanomaru JM, Gonçalves M. Radiopacity evaluation of new root canal filling materials by digitalization of images. J Endod. 2007;33:249-51. 26- Tanomaru-Filho M, Silva GF, Duarte MAH, Gonçalves M, Tanomaru JM. Radiopacity evaluation of root-end filling materials by digitization of images. J Appl Oral Sci. 2008;16:376-9.

27- Wiltbank KB, Schwartz SA, William G, Schindler WG. Effect of selected accelerants on the physical properties of mineral trioxide aggregate and Portland cement. J Endod. 2007;33:1235-8. 